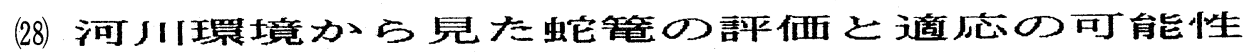

STUDY ON THE EVALUATION ON ENVIRONMENTAL FUNCTIONS OF GABION

\author{
小栗 幸雄*、北川 明*、島谷 幸宏* \\ Sachio OGURI*, Akira KITAGAWA*, Yukihiro SHIMATANI*
}

ABSTRACT; There are flood protection structures such as gabion, fascine mattress and groyne. They have decreased recently, because these methods have problems in mechanization and durability . But they have much environmental potential, in providing landscapes surrounding plants and providing fish and creatures in river which appropriate habitat.

This investigation deals with the evaluation on environmental functions of gabion. The observations and research carried out and following results are obtained.

1. There are gabions which have remained unchanged more than 30 years at the straight reaches in the river.

2. The gabions were naturally covered with plants after about 5 years since they had been constructed.

3. The gabions can be constructed even on steep slope rivers .

KEYWORDS; river environment, traditional flood protection construction, gabion

1・はじめに

本報は、伝統的な治水工法の一つである蛇篭を対象に、その評価および今後の適応の可能性について検討 したものである。蛇篭の評価を行うに際し、現地での観察、専門家あるいは蛇籰協会へのヒアリング、簡易 な計算等種々の手法を用いた。ここでとった評価手法は極めておおゔかみではあるが網羅的であり、環境問 題のような広範囲の領域を扱う分野にとって有効な手法と考えている。

さて河川工事の中で伝統的に使われてきた工法として、蛇籰、粗梁沈床、水制、牛などがある。これらの 工法は機械化が困難であることや耐久性がコンクリート等の素材に比べ劣ること、また職人の確保が困難で あること、それらの効果の定量的な把握が困難であることなどの理由により、しだいに廃れてきているのが 現状である。しかし、これらの工法は長い日本の歴史のなかで近代的な機械や材料を用いる前までに、我国 の風土の中で試練を経て残ってきたものである。それゆえ非力な面もあるが、自然の節理に合ったある種の 合理性備えているはずである。素材の持つ自然さや河状の变動に対する柔らかさ、年月の経緯とともに自 然風景に近い景観を呈するなど、現在行われている近代的な工法にはない良さを持ち合わせている。近年の うるおいや安らぎを求める社会情勢に呼応した、新しい河川事業の展開にとってこれらの伝統的な治水工法

* 建設省土木研究所 Public Works Research Institute of the Ministry of Construction 
が持つ良さから学ぶところは少なくないと思われる。本報は、これらの伝統工法のうち蛇篦を取り上げ、環 境的な視点を含め、その長所、短所を明らかにし、今後の適応の可能性について検討する。

\section{2. 調査方法}

文献調査および、現地における実態調査およびそれを踏まえた解析、蛇篭関係者へのヒアリング調査によ り行った。

実態調査は、大河川（木曽川）、中小河川急流（甲府盆地）、中小河川緩流（房総半島）を対象とした。 甲府盆地の河川はおおむね急流な扇状地河川であり、河床材料も礫のところがほとんどで蛇篭等の材料の玉 石も豊富なところである。また甲府市内を流下する濁川は激特事業で都市部に蛇篭を用いてあり、都市部に おける蛇篦の評価が可能である。一方千葉県房総半島は緩流河川がほとんどであり、その地域全体において も石材がそしく、鴨川地域で蛇紋岩系の長狭石を産するのみの地域である。以上のように甲府盆地と房総半 島は極めて対照的な地域となっており比較検討するのに適している。また、大河川として伝統的治水工法の 事例が比較的豊富な木曾川を対象とする。

ヒアリング調査は、日本蛇篦協会、山梨県、千葉県の当時の施工担当者およびの河川事業の現場経験が豊 富で魚に詳しい建設省OBのS 氏にも行った。生物の評価や耐久性等は現地調査のみで明らかにすることは 困難な場合が多いので、ヒアリングも参考にした。

\section{3. 蛇䈏の現状}

\section{1 歴史的変㟟}

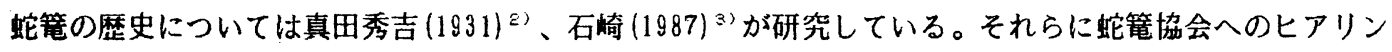
グ結果等を加え简単にまとめてみると、

1) 中国で紀元前 25 年に「竹落」として使われた記述がありそれが最初と思われる。

2)日本では「古事記」に蛇䈕使用の記述があり、そうとう古くから用いられていた。

3)日本において大々的に使われたのは、戦国時代以降である。用材は竹が主であり柳、藤葛、粗梁等も用 いられた。

4) 明治 41 年に蛇篦の製作に亜鉊メッキ鉄線を使用することに成功し、明治42年石川県の犀川護岸工事に始 めて鉄線蛇箽が施工された。

5) その後明治 44 年にそれまで手編みであった鉄線の機械化が図られ普及が進んだ。

6)昭和20〜30年代前半までは災害が多く蛇篭使用のピークを迎えた。

7)現在の蛇篦銅の生産高はおおむね 2 万トン程度であり、

河川災害復旧工事用が需要の大半をしめるが、他の土 木事業の他ゴルフ場、遊園地等の土留や水はけ等、河川以 外の需要が增大している。

\section{2 蛇籰の規格}

蛇篭の規格については、J ISおよび建設省の基準のな かで取り決めてある。その中で示されている蛇篭各部の名 称を図ー 1 に示した。また設置状況の一例を写真ー 1 に示 す。J I S の規格は亜鉊メッキ鉄線の規格を主として定め たもので、寸法および許容誤差、品質、試験などについて 定めている。これは建設省河川局が昭和28年 4月に制定し た”蛇篦の亜鉊引鉄線および構造上の基準”を参考として 昭和32年に制定されたもので、現在のものは昭和 59 年に改
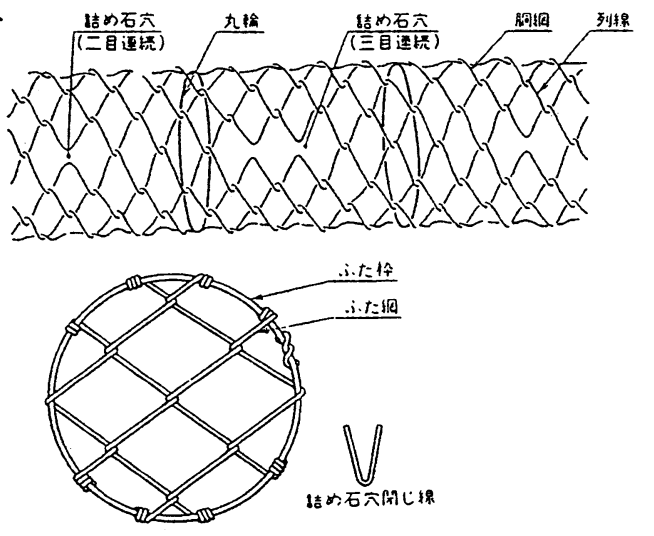

図一 1 蛇篭の形状と名称 


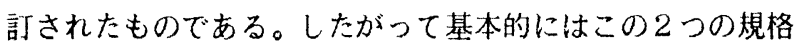
は同じものである。ただしJＩＳの規格では昭和55年の改訂 に伴い長さの規格がとりはずされた。建設省の基準はその後 改訂されておらず、現在に至っている。

\section{3 蛇篦の設置状況}

調査箅所は千葉県 4 ヶ所、山梨県11 ケ所、木曾三川 8 ヶ所 の計23ケ所である。この調査箅所の選定に当たって位置、施 工年度、図面などの資料が比較的揃っているところを県ある いは工事事務所に依頼し選定してもらった。鉄線径は4.0mm( 8 番線)が最多で12 ケ所、3.2 mm (10番線) が3 ケ所、 $5.0 \mathrm{~mm}(6$

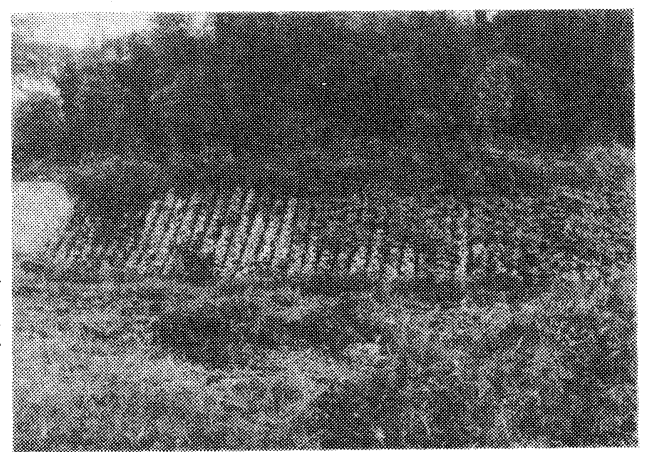

写真 -1 番線)が2 ケ所となっており、J I S 規格あるいは基準の中で一番太い6.0m䊩線)を用いているところは

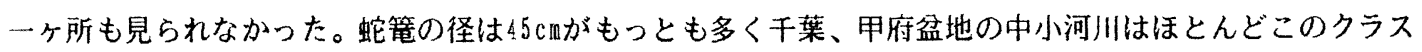

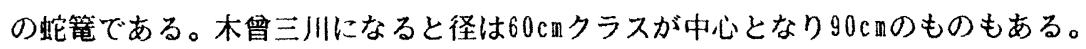

次に蛇篭設置箅所の河床勾配をみてみる。山梨では河床勾配 $1 / 100$ 以下の急流の箇所に蛇篦を用いている。 そのなかで一宮町田垂川で1/15の河床勾配のところに蛇篭を設けている。一方千葉では河床勾配の楥い1/15 00以下の所でも用いられている。これらの河川で用いられている蛇算の大きさに差はない。

表ー 1 に詰め石の入手方法を示した。石材が豊富でない千葉県では、いずれも砕石を用いている。南白黾 川、小櫃川では他県から材料を購入し、大規模な激特事業で行われた小匮川では、山口県、宮城県など遠い 県から石材を購入している。このと きには、山梨県からも石工などを招 いている。一方、山梨県ではすべて の蛇㲘の詰め石が近傍の大河川の河 床から採取した玉石であり、当該河 川の河床材料を用いたところや砕石 を用いたところは一ヶ所もない。近 傍の大河川の材料を用いる理由は、 当該河川のものを用いるよりも、安 価であるためである。

\section{4. 蛇篦の評価}

4,1 蛇筧の長所・短所

表一1 詰め石の入手方法

\begin{tabular}{|c|c|c|c|}
\hline & 河川名 & I 法 & 詰め石の入手万法 \\
\hline \multirow[t]{4}{*}{ 千葉県 } & 南白电川 & 蛇篗・フトン籍 & 㳄城県の笠間碎石 \\
\hline & 小柾川 & 蛇籍 & 宮城累・山口県宇部市 \\
\hline & 加茂川 & フトン籍 & 加茂川市の長狭石（蛇紋岩） \\
\hline & 平久里川 & フトン籠 & II \\
\hline \multirow[t]{8}{*}{ 山梨果 } & 六反川 & 蛇籍 & 釜無川 \\
\hline & 田草川 & $n$ & 埴川 \\
\hline & 秋山川 & " & $\prime \prime$ \\
\hline & 印川 & $\prime \prime$ & 笛吹川水系 \\
\hline & 天川 & $\prime \prime$ & 釜無川 \\
\hline & 田垂川 & $\prime \prime$ & " \\
\hline & 田草川 & $\prime \prime$ & 笛吹川 \\
\hline & 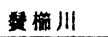 & $\prime \prime$ & 釜無川 \\
\hline
\end{tabular}

蛇篭は屈撓性に富むことや流れに対する抵抗が比較的強い事、安価であること等護岸の素材として優れた 面も多いが、鉄線の寿命に疑問があること、材料の入手が困難であること、職人が不足していることなどの 理由から昭和 40 年代後半より用いられることが少なくなってきている。一方、蛇篦は施工後数年たつと植生 が繁茂し自然景観とほぼ同じ状況を呈し、景観上優れた面があり、また魚類等の生物の生息にも適している と思われる。蛇篦の長所や短所についてはこのように、今まで色々なところで述べられており、現地の状況 を踏まえそれらをまとめると表一 3 左部のようになる。また現地の蛇篭の現状に基づき蛇篭の破填の仕方を 分類してみると以下のようになる。

们流体力による破壊…流される

$$
\text { …鉄線の切断 }
$$

口)地盤の变形による破壊（梁み）

八)化学的作用による鉄線の腐食 
二人間活動による破銥（農作業の車の通行、子供による破填）

これらより現在の蛇篭について次ぎの点を評価する必要がある。

(1)鉄線の切断や腐食に実際どの程度耐えられるか．...䞂久性に関する評価

(2)どの位の掃流力あるいは流速まで耐えられるか．...流水抵抗に関する評価

(3)環境的に蛇䈏は果して良いのか悪いのか．......環境面に関する評洒

なお、施工性の評価は今後の改良を前提にここでは行わない。

\section{2 耐久性の評価}

ここでは先に示した鉄楾の切断および鉄線の腐食について検討してみる。

「蛇籰の亜鉛引き鉄線及び構造上の基準」によれば耐食性は普通の河川の水位部において10年位の耐食度 を有することを目標とするとされている。また日本蛇篭協会へのヒアリングによれば、耐用年数は $10 \sim 15$ 年 とされている。さて現地調査を行った蛇篦のうち竣工年次が明らかな25ヶ所についてその現存状況を表 -2 にまとめた。破壊が見られなかっったのは18事例である。このうち施工後〜 5 年のものは 3 箇所、施工後 6

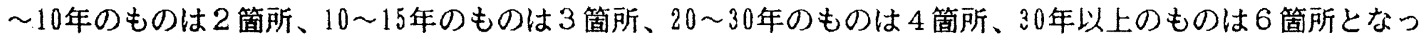
ている。また一部が崩壊したもののうち施工後の年数がもっとも短いのは10年である。なおここに示した一 部崩壊とは蛇篦の一部の金網が腐食等により切断され詰め石の一部が抜け落ちたものをさす。これらを見る ときに注意しなければならないのは、調査した ものは現存しているものに限られており、すで 表 -2 蛇篦工の耐久性 に破壞してしまったものは含まれていない点で ある。

なお、山梨県の甲府盆地の濁川では激特事業 で昭和55〜57年に暫定的な改修として蛇篦で施 エしており、施工後5〜7年が経過している。こ このいずれの筒所も蛇篦の破損や鉄線の腐蝕や 切断は見られない。渴川は甲府市内東部を流下 する河川であり、この沿川は下水道が末整備な こともあり水質は良好とは言えないが、鉄線に とって有害な水筫（例えば酸性）の河川ではな い。

これらのことから考察すると普通の水質のと ころでは4 5年で腐蝕することはなく、少なく

\begin{tabular}{|c|c|c|c|c|}
\hline 兒 状 & 千尊河川 & 甲東河川 & 木目三川 & 尌 \\
\hline 完全に維持 & 4 & 9 & 6 & 19 \\
\hline 一部の鉄㷧破断 & 1 & 1 & 2 & 4 \\
\hline 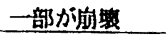 & 0 & 1 & 0 & 1 \\
\hline 杂み & 0 & 1 & 0 & 1 \\
\hline 完全に湖湛 & 0 & 0 & 0 & 0 \\
\hline 合 計 & 5 & 12 & 8 & 25 \\
\hline
\end{tabular}

とも10年以上の耐久性はあると考えて良い。

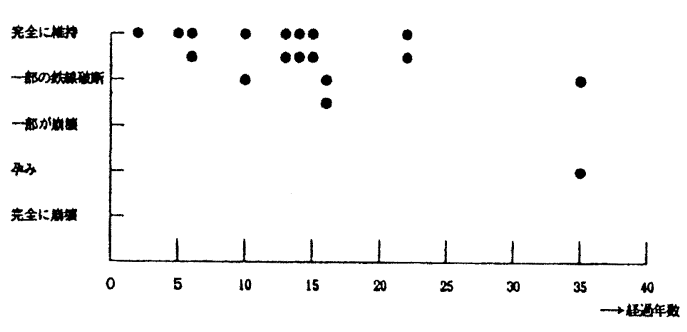

\section{3 流水抵抗に関する評価}

護岸の破填の原因は色々あるが主として 3 つ程度に分類できる。1つは流送されてきた樹木や岩石が衝突 し、護岸自体が強度的に持たず破壊する場合である。次は流体力により護岸が滑動あるいは転動して破壊す る場合である。もう一つは護岸の根が洗掘され破壊に至る場合である。このうち最後の根の洗掘によるもの が護岸の倒填の主たる原因といわれている。

さて蛇篭の場合、個々の材料を充填したものであるため屈暁性があり、一本の重量が相当重いため（直径 $45 \mathrm{~cm}$ 、長さ $4 \mathrm{~m}$ で約 1 ． 5 ton/本) 根の洗掘や流体力に対する抵抗が強いことが想像される。ここでは現地 実態調查に基づき一例を検討する。

対象とするのは、山梨県管理の一級河川田草川である（図-2、3参照）。流域面積約 $7 \mathrm{~km} \mathbb{\pi}^{2}$ の小河川で あるが、昭和25年の災害の後、災害助成工事で重川との合流点から約 $3.5 \mathrm{~km}$ 区間全川にわたり蛇篭を用いた 工事が実施された。その後総雨量 $300 \mathrm{~mm}$ 以上の大降雨 3 回等の出水を経たにもかかわらず、直楾区間を中心 
におよそ約 3 割程度が現存している。その他の部分はその後の災害復旧工事によりブロック積に改修されて いる。

現地調查ヒアリングによれば近年最も水位が上がったのは地点 $\mathrm{A}$ の水管橋で桁下約 $1 \mathrm{~m}$ 程度であり、これ までに記録された時間最大降雨量は $50 \mathrm{~mm} / \mathrm{hr}$ であった。合理式によりこの時のピーク流量を計算すると約 78 msによなる。ただし $\mathrm{f}=0,8$ 、到達時間は 1 時間と仮定し計算した。比較的直線であり、蛇篦が現存している区

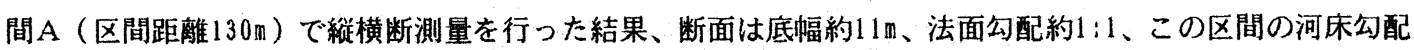
は約1/30であった。

等流でこの時の流速及び流量を計算してみる。粗度係数を $\mathrm{n}=0.04$ と仮定すると、

$$
\begin{aligned}
& \mathrm{V}=1 / \mathrm{n} \cdot \mathrm{R}^{2 / \mathrm{s}} \cdot \mathrm{I}^{1 / 2}=1 / 0.04 \times 1.48^{2 / 3} \times(1 / 30)^{1 / 2}=5.9 \mathrm{~m} / \mathrm{s} \\
& \mathrm{Q}=\mathrm{A} \times \mathrm{V}=5.9 \times 24.5=144 \mathrm{~m} / \mathrm{s}
\end{aligned}
$$

となる。また、現地でヒアリングの水位が多少異なっていたと仮定し、水位を0.6程度低くし、1.3n程度と すると、流出計算時の流量にほぼ一致し、 $\mathrm{V}=4,8 \mathrm{~m} / \mathrm{s} 、 \mathrm{Q}=76 \mathrm{~m} / \mathrm{s}$ となる。また、ヒアリングの水位は正しく なんらかの原因で動水勾配がもう少し小さく、ほぼ流出計算と同じ流量が流下していたと仮定すれば V =3. $2 \pi / s$ となる。

詳細な抗力、揚力等は実験的椿討を待たなければならないが、少なくとも流速 $3 \mathrm{~m} / \mathrm{s}$ 以上の流れに対しても 直線部では残存したという結果を得た。この事例より流水抵抗もかなり大きいと評価できる。

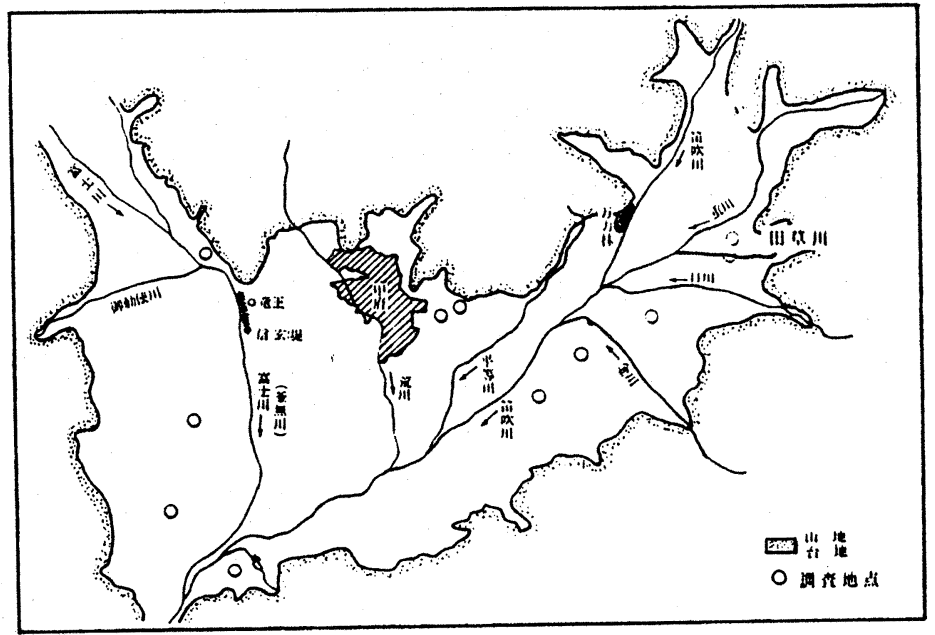

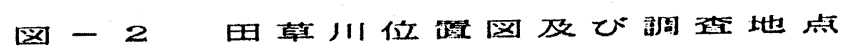

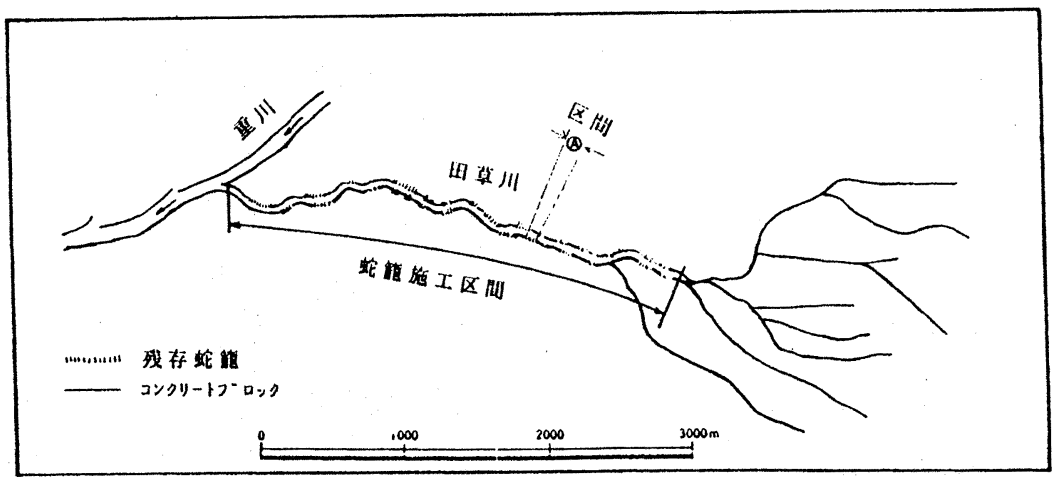

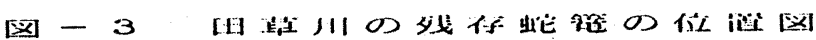




\section{4 環境面に関する評価}

河川の環境を考える場合、種々の要素があるが、主として(1)景観、(2)親水活動、(3)生物の保全の3 点を考 えておけば良い。

まず景観について考えれば自然景観なのか、人工景観なのかを区別して考えた方がよい。周辺が自然景観 の場合は、なるべく人の手の入っていない印象を与える物が望ましく、周辺の自然植生に近いものが繁茂し うるかどうかが重要となる。また、素材自体の見え方が自然的かどうかも重要である。その点蛇篭は材料自 体は自然材であり、しかも植物が繁茂しやすい状況にあるので自然景観にはなじむ構造物と考えることがで きる。ただし鉄線でできているため、それが視認できる距離では人工的な印象を与える場合があり改良する 余地がある。現地調査によれば蛇篦の場合 5 年もたてば十分に周辺とほぼ同じ植生が繁茂し、自然景観に近 い状況になる。一方、周辺が都市の場合は草が非常に繁茂するため、手入れをしなければ雑然としてうっと うしい風景になりかねない。

親水性すなわち、水への触れやすさ活動のしやすさという点は、ブロック護岸や階段護岸より劣る。蛇篦 の場合同じ勾配のブロックに比べると、蛇篭が丸い、石と石の間に足が入る、鉄線の編目に足が入るなど足 場の問題がある。フトン篭の場合は階段状になっているため利用しやすくなるが、網目に足が入るなど足場 の不安定さの問題は残る。

次に生物の保全に関する検討は、現地調査が困難な場合が多いので、ヒアリング結果をまとめるにとどめ る。ヒアリングによれば、(1)空石積み、乱積みの護岸にはナマズ、谩、鯉、フナなどがいる。空隙、隠れ場 所があるところには魚がいる。(2)ブロックを數並べて、護岸もコンクリートのところには魚はいない。すな わち䧌れ場、空隙がない。(3)コンクリートのように表面がざらざらしているものは、魚とあわない、自然の 石はツルツルだからである。(4)水制でも魚がいるところは、石があるところに限られる。(5)蛇篭は、鰻とナ マズが多いなどの意見を持っている。すなわち、隙間がたくさんある充填構造であること及び自然石の表面 の滑らかさが魚のすみかの要因となっているようである。

以上のように蛇篦は自然風景になじみ生物の生息の場を提供するので、自然環境を創造・保全する区域に おいては、有効な工法と環境上評価できる。

\section{5. 今後の蛇篦の適応の可能性}

蛇篭の形態上、構造上の特徵と長所・短所の関係及び今後の適応への配慮を表ー 3 にまとめた。要約する と蛇篭は網状で被された石材の充填構造物であり、1本 1 本が分離する比較的重たい護岸施設という特色を 持つ。これらの形態上、構造上の特徴が治水・環境面に多くの利点をもたらしている。現在の工法にはこの ような特色を持つ構造物はなく、これらの機能を保持し現場への適用を図ることが望まれる。ただし鉄材で あることによる耐久性の問題、円柱上あるいは充填構造による機械化が困難であることなどの問題がある。 円柱状である必然性はほとんどなく、形状を四角柱にするなど機械化が促進する方向への改善が必要である。 現在、筆者等は蛇篭網の材質・形状について検討中であり、これらが改善されれば蛇籰の現地への適用の可 能性は高まると思われる。

\section{参考文献}

1)北川、島谷、小栗「伝統的治水工法に関する調査（その1）」土木研究所資料第2622号

2) 真田秀吉「日本水制工論」岩波書店 1932

3)石猗正和「蛇篭に関する歴史的考察」第 7 回日本土木史研究会論文集1987

4)「蛇篦の知識」(社) 全国防災協会

5)「蛇篭の亜鉊引鉄線及び構造上の基準」建設省河川局 1953.4 


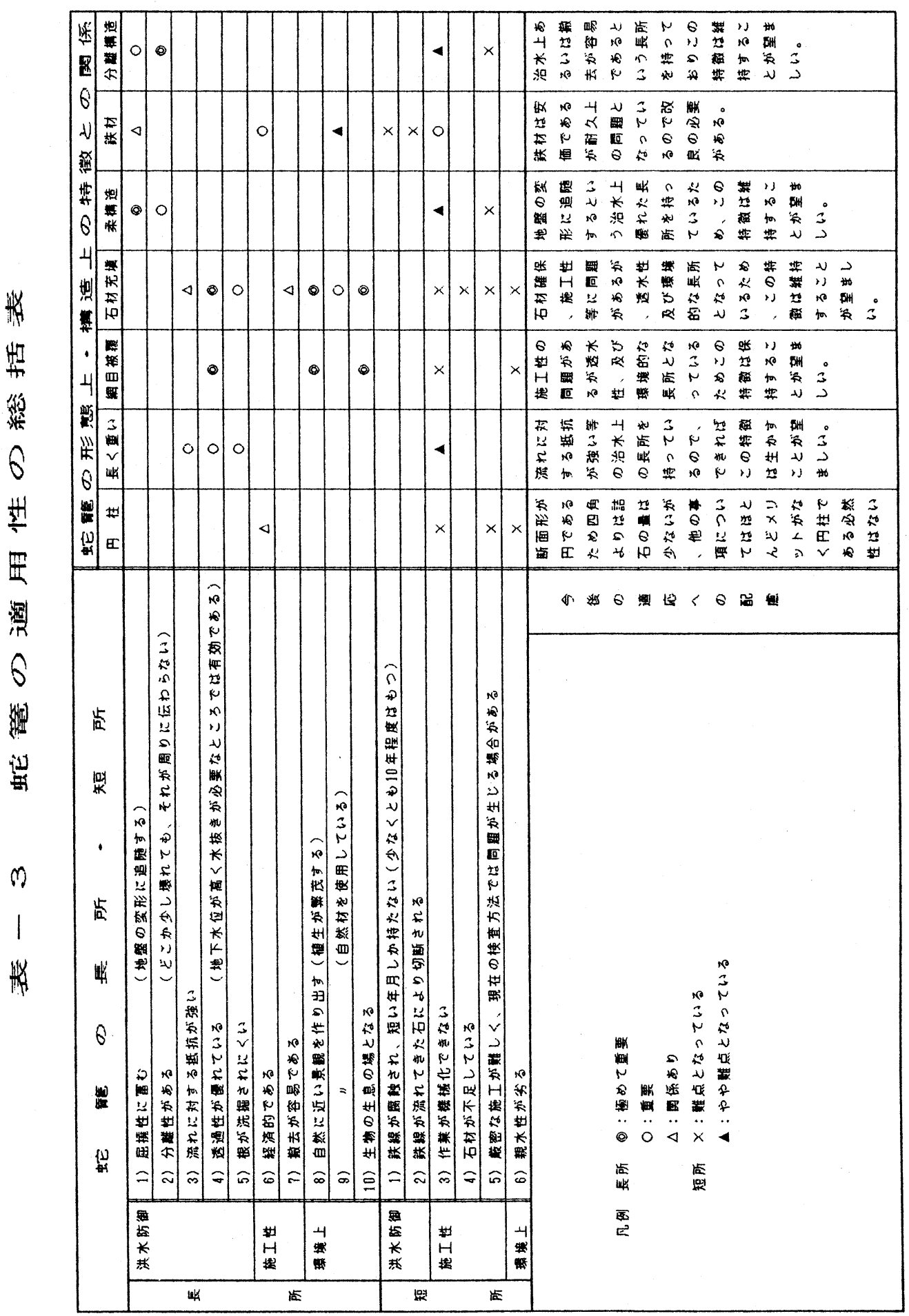

